\title{
Medium and time conservation affect follicular morphology and superoxide dismutase enzyme activity of bovine preantral follicles during storage at $4^{\circ} \mathrm{C}$
}

\section{Meio e tempo de conservação afetam a morfologia folicular e atividade da enzima superóxido dismutase de folículos pré-antrais bovinos durante a conservação a $4{ }^{\circ} \mathrm{C}$}

\author{
Maiara Aline Gonçalves Ramos ${ }^{1}$; Fabio Gallas Leivas²; Daniele Missio ${ }^{3}$; \\ Francielli Weber Santos Cibin²; Antônio Carlos Galarça Guimarães ${ }^{4}$; \\ Daniela dos Santos Brum ${ }^{2 *}$
}

\section{Highlights:}

Time conservation directly influences follicular viability.

TCM 199 at $4^{\circ} \mathrm{C}$ for $6 \mathrm{~h}$ can be used to conserve female bovine PFs in situ.

TCM 199, saline or PBS for $24 \mathrm{~h}$ incubation is not effective for maintaining bovine PF.

\begin{abstract}
The aim of this study was to evaluate the morphology and superoxide dismutase enzyme (SOD) activity of bovine preantral follicles (PFs) preserved in TCM 199, saline solution or PBS at different conservation periods. Cow ovaries $(n=6)$ were divided into 7 fragments. One small piece of each ovarian fragment was randomly removed to evaluate SOD activity, while the remainder was immediately fixed for morphological evaluation as a control group. The other 6 fragments were randomly distributed in tubes containing TCM 199, saline solution, or PBS and maintained at $4^{\circ} \mathrm{C}$ for 6 or $24 \mathrm{~h}$. For histological evaluation, the fragments were fixed in Carnoy and stained with PAS-hematoxylin, following being classified PFs in relation to their follicular morphology in normal or degenerated. Determination of SOD activity was based on the ability to inhibit autoxidation of adrenaline in adrenochrome. Evaluation of follicular morphology showed that follicles preserved in TCM 199 for $6 \mathrm{~h}$ did not differ from the control $(\mathrm{P}>0.05)$. In contrast, preservation in saline solution and PBS for 6 or $24 \mathrm{~h}$ and TCM 199 for $24 \mathrm{~h}$ decreased normal PFs compared to the control $(\mathrm{P}<0.05)$. SOD showed a lower activity in ovarian cortical tissue kept in TCM 199 for $6 \mathrm{~h}$ and saline solution for $24 \mathrm{~h}$ than in the other groups. Our study shows that incubation using TCM 199 at $4{ }^{\circ} \mathrm{C}$ for $6 \mathrm{~h}$ can be used to efficiently conserve female bovine PFs in situ.
\end{abstract}

Key words: Ovary. Oxidative stress. Preservation.

\footnotetext{
1 Médica Veterinária Autônoma, M.e em Patologia Veterinária, Universidade Federal do Rio Grande do Sul, UFRGS, Porto Alegre, RS, Brasil. E-mail: maiaragonçalvesrs@hotmail.com

2 Profs., Curso de Medicina Veterinária, Universidade Federal do Pampa, UNIPAMPA, Uruguaiana, RS, Brasil. E-mail: fabioleivas@unipampa.edu.br; danielabrum@unipampa.edu.br; franciellicibin@unipampa.edu.br

3 Discente do Programa de Pós-graduação em Medicina Veterinária, Universidade Federal de Santa Maria, Santa Maria, RS, Brasil. M.e em Ciência Animal, Universidade Federal do Pampa, UNIPAMPA, Uruguaiana, RS, Brasil. E-mail: daniele.missio@ mail.ufsm.br

4 Técnico Administrativo em Educação, UNIPAMPA, Uruguaiana, RS, Brasil. E-mail: antonioguimaraes@unipampa.edu.br

* Author for correspondence
} 


\section{Resumo}

O objetivo desse estudo foi avaliar a morfologia e atividade da enzima superóxido dismutase (SOD) de folículos pré-antrais bovinos (PFs) preservados em TCM 199, solução salina ou PBS por diferentes períodos de conservação. Ovários de vacas $(\mathrm{n}=6)$ foram divididos em 7 fragmentos. Um pequeno pedaço de cada fragmento ovariano foi removido para avaliar a atividade da SOD enquanto que o restante foi imediatamente fixado para avaliação morfológica como grupo controle. Os outros 6 fragmentos foram distribuídos aleatoriamente em tubos contendo TCM 199, solução salina ou PBS e mantidos a $4^{\circ} \mathrm{C}$ por 6 ou 24 h. Para avaliação histológica, os fragmentos foram fixados em Carnoy e corados com PAShematoxilina, sendo classificados em seguida os PFs em relação à sua morfologia folicular em normal ou degenerados. A determinação da atividade da SOD foi baseada na capacidade de inibir a autooxidação da adrenalina no adrenocromo. A avaliação da morfologia folicular mostrou que os folículos preservados em TCM199 por $6 \mathrm{~h}$ não diferiram do controle $(\mathrm{P}>0,05)$. Em contraste, a preservação em solução salina e PBS por 6 ou 24 h e TCM 199 por 24 h diminuiu os PFs normais em comparação com o controle $(\mathrm{P}<0,05)$. A SOD mostrou uma menor atividade no tecido cortical ovariano mantido em TCM 199 por 6 h e solução salina por $24 \mathrm{~h}$ do que nos outros grupos. Nosso estudo mostra que a incubação usando TCM 199 a $4^{\circ} \mathrm{C}$ por $6 \mathrm{~h}$ pode ser usada eficientemente para conservar PFs de fêmeas bovinas in situ.

Palavras-chave: Estresse oxidativo. Ovário. Preservação.

\section{Introduction}

Ovarian mammals contain thousands of oocytes in preantral follicles (PFs), but only a small portion $(0.1 \%)$ will be used during the female reproductive lifespan (Costa et al., 2002). The biotechnology of oocyte manipulation included in preantral ovarian follicles currently occupies an important place in assisted reproduction techniques (ARTs) for both animals and humans, because it allows PFs to be recovered and cultured in vitro before they become atresic. In addition, it is an important tool for basic research on the physiological mechanisms of folliculogenesis, contributing to the preservation of genetic material from endangered animals (Figueiredo, Rodrigues, \& Amorin, 2008).

In vitro culture of isolated or in situ has satisfactory results. However, preservation of follicular viability during ovary transport is a limiting factor for this biotechnological approach. Several studies have demonstrated that quality of oocytes enclosed in PFs is dependent on preservation medium, temperature, and time conservation during the transport of ovaries (Barberino, Silva, Figueiredo, \& Matos, 2019). Female gamete preservation can be better achieved by storing pieces of ovarian tissue containing numerous immature small oocytes enclosed within PFs (Paynter, 2000). Time conservation directly influences follicular viability. As ovaries are normally collected at sites far from laboratories (Celestino et al., 2007), it is essential to establish an efficient protocol for bovine $\mathrm{PF}$ preservation.

Reactive oxygen species (ROS) accumulation, possibly generated during transport and cooling of the ovarian tissue, should also be considered. ROS can result in high free radical rates and promote significant cellular damage (Lima-Verde et al., 2009). To neutralize ROS and minimize damage to cellular structures, there are antioxidant defense mechanisms found in various tissues of the organism. Among these factors, the superoxide dismutase (SOD) enzyme is the first enzymatic step in protecting cells from toxic ROS (Sugino, 2007). In humans and rodents, SOD has been investigated as a marker of oxidative stress in the granulosa cells of both preantral and antral follicles (Matzuk, Dionne, Guo, Kumar, \& Lebovitz, 1998; Suzuki et al., 1999; Combelles, Holick, Paolella, Walker, $\& \mathrm{Wu}, 2010$; Wang et al., 2017). In addition, SOD activity is directly related to oocyte quality and 
can be considered an ART biomarker (Combelles et al., 2010). Given the effect of medium and time conservation on ROS production and follicular morphology, the aim of this study was to evaluate the influence of media (TCM 199, saline solution at $0.9 \%$, and PBS) and storage time (6 or 24 hours), on the SOD activity and morphology of bovine preantral follicles preserved in situ at $4^{\circ} \mathrm{C}$.

\section{Materials and Methods}

\section{Experimental protocol}

Ovaries ( $\mathrm{n}=6)$ from six Bos taurus cows were collected at a local slaughterhouse immediately after slaughter and transported to the laboratory in saline solution $(0.9 \% \mathrm{NaCl})$ at $4^{\circ} \mathrm{C}$. In the laboratory, the cortical layer was fragmented and subjected to different treatments ( $3 \times 2$ factorial) in accordance with the medium or time used for the simulated transport. For control purposes (control time 0), a small piece of ovarian fragment was randomly removed to evaluate SOD activity. The remainder was immediately fixed in Carnoy for histological examination. The other 6 fragments were randomly distributed into tubes containing $15 \mathrm{~mL}$ of TCM 199 (Tissue Culture Medium with 25 mmol HEPES, St. Louis, MO, USA), $0.9 \%$ saline solution, or PBS (phosphate-buffered saline, Nutricell, Campinas, SP, Brazil). All samples were then stored at $4^{\circ} \mathrm{C}$ for 6 or 24 h (Figure 1). Each treatment was repeated six times.

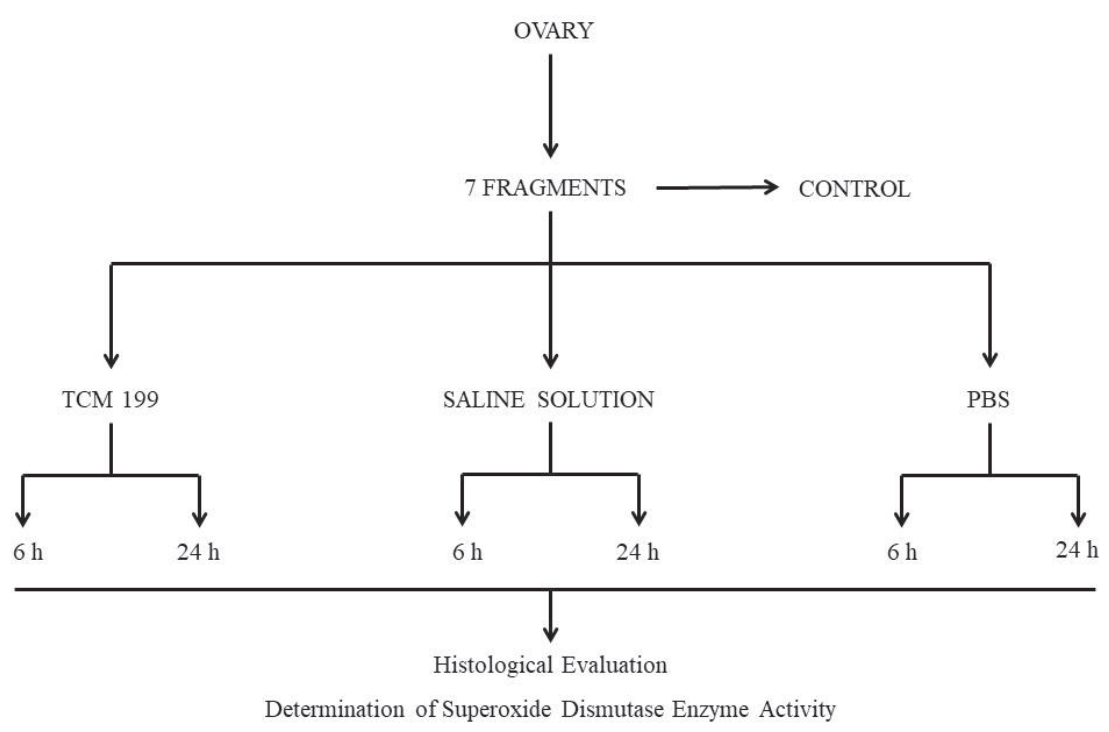

Figure 1. Experimental protocol for conservation in situ of bovine preantral follicles in ovarian pieces.

\section{Histological evaluation}

In order to evaluate the morphology of the bovine preantral follicles at the end of treatments, the ovarian fragments were processed as follows. Small pieces of ovarian fragments were removed from each treatment, including the Control, and fixed in Carnoy for $12 \mathrm{~h}$. Following this, they were dehydrated in a graded series of ethanol, clarified with xylol, and embedded in paraffin wax. The tissue was sectioned serially at a thickness of $5 \mu \mathrm{m}$ and stained with PAS-hematoxylin. Each section was examined by light microscopy (Olympus Cx31, Tokyo, Japan) under $400 \times$ magnification.

Follicle morphology was evaluated based on the integrity of the basement membrane, density of the granulosa cells, presence of pycnotic bodies, and 
integrity of the oocyte using nucleus as a marker (Figure 2). Based on these parameters, PFs were classified as morphologically normal (containing an intact oocyte and well-organized granulosa cells without a pycnotic nucleus) or degenerated (containing an oocyte with cytoplasmic retraction, pycnotic nucleus, and disorganized granulosa cells). Preantral follicles were classified as primordial (one layer of flattened or flattened-cuboidal granulosa cells around the oocyte), primary (one layer of cuboidal granulosa cells around the oocyte) and secondary (two or more layers of cuboidal granulosa cells around the oocyte), according to their developmental stage (Hulshof, Figueiredo, Beckers, Bevers, \& Van Den Hurk, 1994) and a total of 60 PFs were evaluated for each treatment.

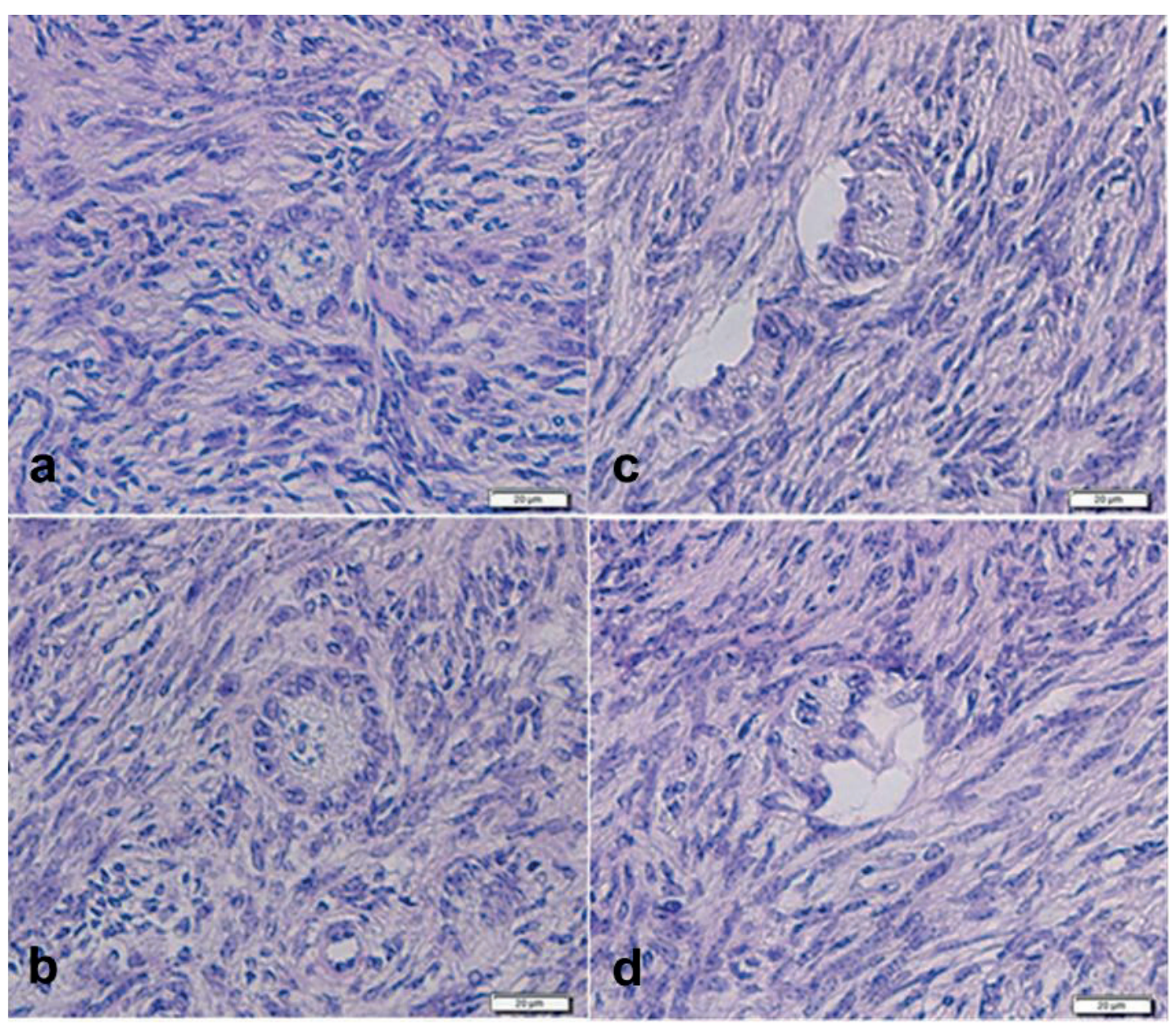

Figure 2. Follicle classification according to morphological appearance.

(a-b) Morphologically normal follicles $(400 \times)$, with a round oocyte surrounded by well-organized granulosa cells and integral nucleus; (c-d) Degenerate follicles $(400 \times)$, with degenerate oocyte with pycnotic nucleus and disorganized granulosa cells the low cellular density. PAS-hematoxylin stained.

\section{Superoxide dismutase enzyme activity}

Superoxide dismutase enzyme activity in the tissue was determined as described by Misra and Fridovich (1972). This method is based on the ability of SOD to inhibit the auto-oxidation of epinephrine to adrenochrome. The color reaction can be monitored at $480 \mathrm{~nm}$. One enzymatic unit (1 IU) was defined as the amount of enzyme necessary to inhibit the epinephrine auto-oxidation rate by $50 \%$ at $26^{\circ} \mathrm{C}$. 


\section{Statistical analysis}

The effect of medium (saline solution, TCM 199 or PBS) and time (6 or $12 \mathrm{~h}$ ) conservation on the percentage of morphologically normal follicles and SOD activity was analyzed using ANOVA and Tukey tests. Values were considered statistically significant when $\mathrm{P}<0.05$.

\section{Results}

The effects of medium and time conservation on the percentage of normal PFs stored at $4^{\circ} \mathrm{C}$ analyzed in this study are shown in Figure 3. A percentage of normal PFs stored in TCM 199 (51.7\%) for up to $6 \mathrm{~h}$ was similar $(\mathrm{P}>0.05)$ to the control group (time zero; 66.7\%). A significant decrease in the follicular viability as compared to the control was observed when PFs were stored in saline solution
(20 and 16.7\%) or PBS (36.7 and 21.7\%), at 6 and $24 \mathrm{~h}$, respectively, or in TCM 199 for $24 \mathrm{~h}$ $(33.3 \%)$. When the effect of incubation time in each medium was analyzed, the percentage of morphologically normal follicles was affected by incubation time in TCM 199. However, incubation period had no affect when using saline solution and PBS ( $\mathrm{P}>0.05$ ). The comparison of the TCM 199 saline solution, and PBS, for the same incubation period, showed a significantly higher percentage of morphologically normal follicles in TCM 199 than in the saline solution at $6 \mathrm{~h}$. However, TCM 199 and PBS produced similar numbers of morphologically normal follicles. At $24 \mathrm{~h}$ of incubation, there was no difference viability between the medium used $(\mathrm{P}>0.05)$.

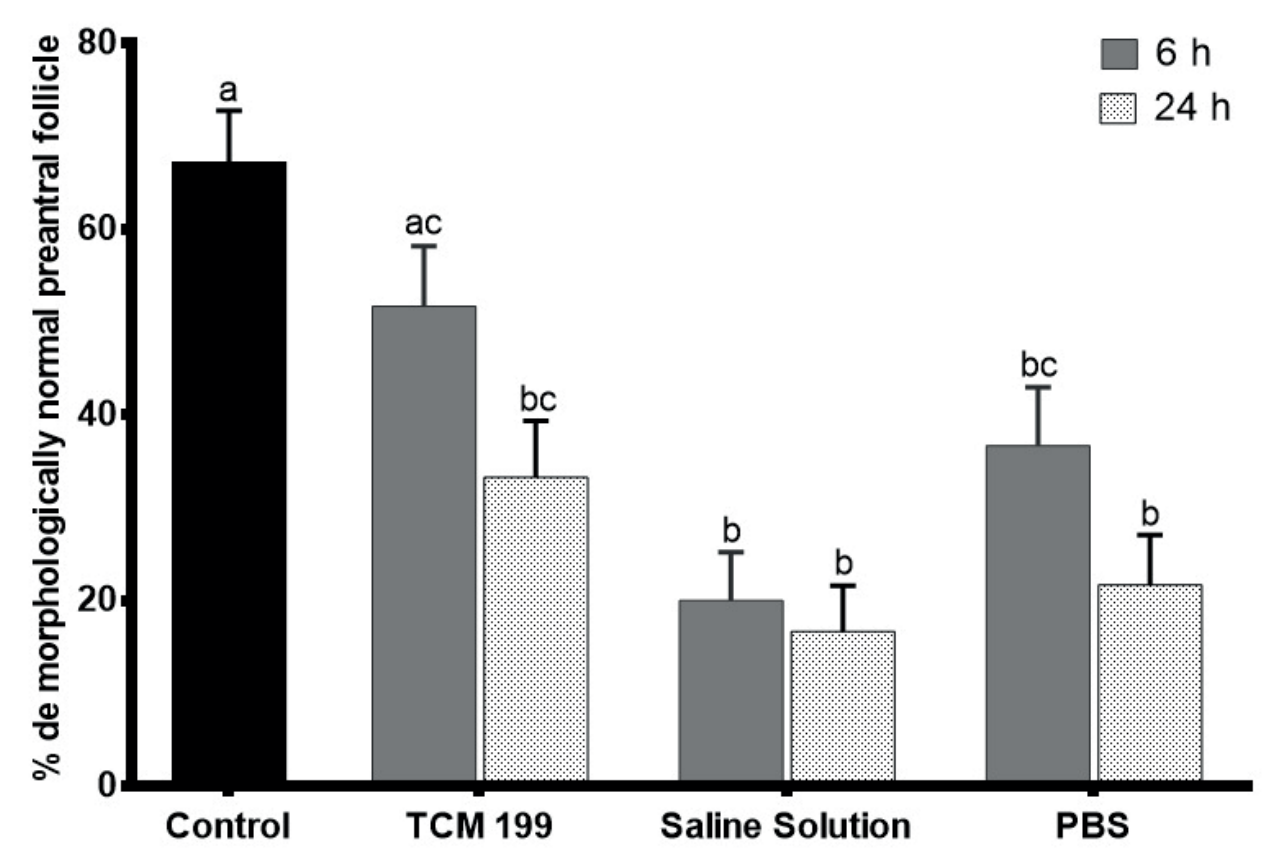

Figure 3. Effect of medium and time conservation at $4^{\circ} \mathrm{C}$ on the percentage of morphologically normal preantral follicles.

${ }^{a b c}$ Different letters differ significantly $(\mathrm{P}<0.05)$.

There was a reduction in ovarian enzyme activity when TCM 199 or saline solution was employed for $24 \mathrm{~h}$ and compared to the control (Figure 4). TCM
199 and saline solution for $6 \mathrm{~h}$ and PBS for 6 or 24 $\mathrm{h}$ did not differ from the control or between groups $(\mathrm{P}<0.05)$. 


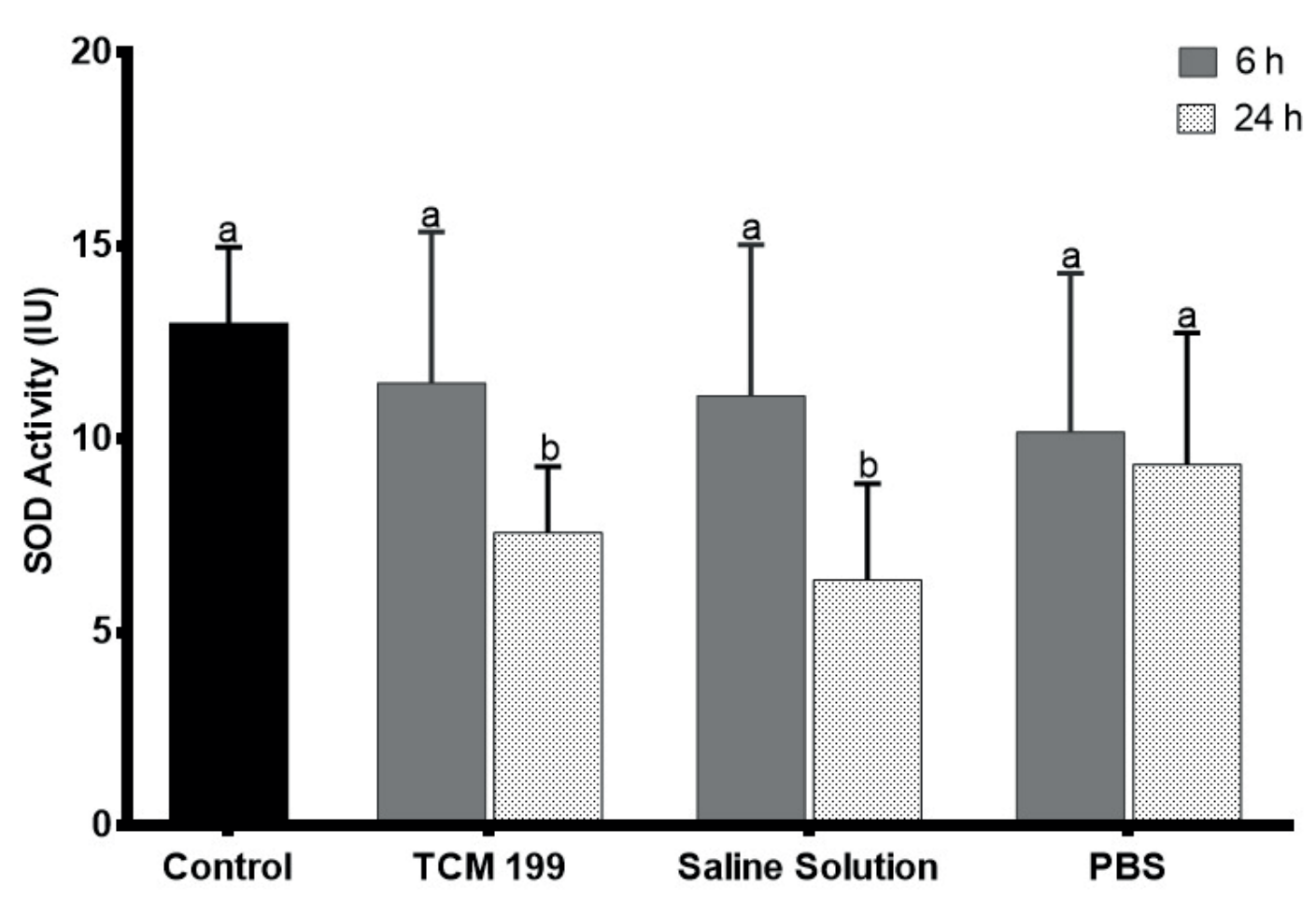

Figure 4. Effect of medium and time conservation at $4^{\circ} \mathrm{C}$ in the superoxide dismutase enzyme activity.

${ }^{\text {abc }}$ Different letters differ significantly $(\mathrm{P}<0.05)$.

\section{Discussion}

This study showed that it is possible to successfully preserve bovine PFs, enclosed in ovarian tissue, in TCM 199 for up $6 \mathrm{~h}$ without altering the SOD activity. PFs of bovine females can be effectively conserved when TCM 199 is used (Mclaughlin, Bromfield, Albertini, \& Telfer, 2010). However, the efficiency of TCM 199 storage is variable according to the incubation period. In this study, TCM 199 showed the best follicular morphology when used for $6 \mathrm{~h}$. Other studies have shown that bovine (Celestino et al., 2007), sheep (Andrade et al., 2002), feline (Missio, Rosa, Guimarães, Leivas, $\&$ Brum, 2014), and goat (Ferreira et al., 2001) preantral follicles can be maintained in TCM 199 for up to $24 \mathrm{~h}$ at $4^{\circ} \mathrm{C}$, with no changes in follicular morphology.

Many studies have indicated saline solution to be a viable medium for ovary transport (Lucci et al., 1999) and preservation of PFs in situ in different species including: sheep (Andrade et al., 2002; Matos et al., 2004), goats (Carvalho et al., 2001; Costa et al., 2002), and cattle (Lucci, Kacinskis, Rumpf, \& Báo, 2004). However, saline solution and PBS did not efficiently conserve PF compared to the control, even when used for short periods. Celestino et al. (2007) demonstrated that bovine PF morphology was impaired when maintained in saline solution as compared to TCM 199. Nonetheless, in goats, the use of saline solution and PBS were effective for follicular conservation for 12 and $24 \mathrm{~h}$, respectively (Santos et al., 2002).

Though PFs have two nutrients sources, intracellular and preservation medium, the composition of medium is important to the preservation of follicular viability when storage times or temperatures are increased (Carvalho et al., 2001; Celestino et al., 2007). According to Salehi, Spratlin, Chong and Churchill (2004), there is a rapid depletion of cellular energetic stocks 
during prolonged storage that results in medium acidification. Despite the fact that TCM 199 is rich in nutrients (Migliorisi, Folkes, Pawlowski, \& Cramer, 1987), which possibly contributed to a greater conservation of follicular integrity, in this study, it was not efficient at ovarian tissue maintenance for $24 \mathrm{~h}$. Therefore, PBS proved to be a viable alternative for PF conservation. Despite a significant difference between PBS and the control, PBS was similar to TCM 199 up to $6 \mathrm{~h}$ and superior to saline solution. These data suggest that, despite the poor nutrient content of PBS, its buffered nature may prevent acidification of the medium for short durations.

ROS production occurs naturally during cellular metabolism or in biological disorders (Gigli, Byrd, \& Fortune, 2006). Oxidative stress is caused by an imbalance between ROS production and neutralization by antioxidants, resulting in damage to cellular components such as lipids, proteins, and DNA (Valko et al., 2007). Among the antioxidants, SOD is the main antioxidant enzyme, and its level is therefore considered an important parameter of oxidative damage determination (Sun, Oberley, \& Li, 1988; Zhang et al., 2013). SOD metabolizes superoxide radicals to hydrogen peroxide, which is further metabolized to water and oxygen by catalase or glutathione peroxidase (Agarwal, Gupta, \& Sharma, 2005; Sugino, 2007). Therefore, decreased SOD activity in ovarian tissue preserved in TCM 199 and saline solution for $24 \mathrm{~h}$ suggests oxidative stress in these groups. Reduced SOD activity occurs because of the consumption of medium components such as salts, amino acids, and vitamins, which are necessary for follicle maintenance and survivals. In addition, SOD activity, associated with the histological evaluation, demonstrated that TCM 199 and saline solution are not efficient in follicular preservation for $24 \mathrm{~h}$. While the SOD activity in TCM 199 and saline solution for $6 \mathrm{~h}$ and PBS for both 6 and $24 \mathrm{~h}$ did not differ from the control, only treatment with TCM 199 for up to $6 \mathrm{~h}$ was similar to the control with regards to follicular morphology. Considering that histological evaluation demonstrated that incubation with PBS for up to $24 \mathrm{~h}$ was not effective for PF conservation, and SOD activity in this group was similar to the control. Although PBS prevented the formation of ROS, this medium did not prevent follicular atresia. Thus, it is not a good medium for ovarian tissue preservation.

\section{Conclusion}

The morphological evaluation of bovine PFs preserved in saline solution and PBS suggests that these media are not efficient in follicular morphology maintenance. The evaluation of SOD activity in ovarian tissue can be used as a tool to determine oxidative stress in tissues maintained in different media for different durations of time. Therefore, the evaluation of the SOD activity, combined with histological evaluation, suggests that $24 \mathrm{~h}$ incubation is not effective for bovine PF maintenance in TCM 199, saline solution, or PBS. In contrast, TCM 199 medium at $4^{\circ} \mathrm{C}$ preserved follicular morphology without altering SOD activity for up to $6 \mathrm{~h}$ and can be efficiently used in protocols for conservation of preantral follicles from bovine females.

\section{References}

Agarwal, A., Gupta, S., \&0 Sharma, R. K. (2005). Role of oxidative stress in female reproduction. Reproductive Biology and Endocrinology, 3(28), 1-21. doi: 10.1186/1477-7827-3-28

Andrade, E. R., Amorim, C. A., Costa, S. H. F., Ferreira, M. A. L., Rodrigues, A. R. R., Dode, M. A. N., \& Figueiredo, J. R. (2002). Preliminary study of shortterm preservation of ovine ovarian tissue containing preantral follicles in saline solution of TCM199. The Veterinary Record, 151(15), 452-453. doi: 10.1136/ vr.151.15.452

Barberino, R. S., Silva, J. R. V., Figueiredo, J. R., \& Matos, M. H. T. (2019). Transport of domestic and wild animal ovaries: a review of the effects of medium, temperature, and periods of storage on follicular viability. Biopreservation and Biobanking, 17(1), 84-90. doi: 10.1089/bio.2018.0057 
Carvalho, F. C., Lucci, C. M., Silva, J. R., Andrade, E. R., Báo, S. N., \& Figueiredo, J. R. (2001). Effect of Braun-Collins and Saline solutions at different temperatures and incubation times on the quality of goat preantral follicles preserved in situ. Animal Reproducion Science, 66(3-4), 195-208. doi: 10.1016/S0378-4320(01)00085-9

Celestino, J. J. H., Santos, R. R., Martins, F. S., Matos, M. H. T., Figueiredo, J. R., Costa, S. H. F.,... Rodrigues, A. P. R. (2007). Conservação de folículos pré-antrais bovinos em solução salina $0,9 \%$ ou TCM 199. Arquivo Brasileiro de Medicina Veterinária e Zootecnia, 59(3), 591-599. doi: 10.1590/S010209352007000300007

Combelles, C. M., Holick, E. A., Paolella, L. J., Walker, D. C., \& Wu, Q. (2010). Profiling of superoxide dismutase isoenzymes in compartments of the developing bovine antral follicles. Reproduction, 139(5), 871-881. doi: 10.1530/REP-09-0390

Costa, S. H. F., Santos, R. R., Ferreira, M. A. L., Machado, V. P., Rodrigues, A. P. R., Ohashi, O. M., \& Figueiredo, J. R. (2002). Preservation of goat preantral follicles in saline or coconut water solution. Brazilian Journal of Veterinary Research and Animal Science, 39(6), 324-330. doi: 10.1590/ S1413-95962002000600009

Ferreira, M. A., Brasil, A. F., Silva, J. R., Andrade, E. R., Rodrigues, A. P., \& Figueiredo, J. R. (2001). Effects of storage time and temperature on atresia of goat ovarian preantral follicles held in M199 with or without indole-3-acetic acid supplementation. Theriogenology, 55(8), 1607-1617. doi: 10.1016/ s0093-691x(01)00506-4

Figueiredo, J. R., Rodrigues, A. P. R., \& Amorin, C. A. (2008). Manipulação de oócitos inclusos em folículos ovarianos pré-antrais. In P. B. D. Gonçalves, J. R. Figueiredo \& Freitas V. J. F. (Ed.), Biotécnicas aplicadas à reprodução animal (pp. 303-328). São Paulo: Roca.

Gigli, I., Byrd, D. D., \& Fortune, J. E. (2006). Effects of oxygen tension and supplements to the culture medium on activation and development of bovine follicles in vitro. Theriogenology, 66(2), 344-353. doi: 10.1016/j.theriogenology.2005.11.021

Hulshof, S. C. J., Figueiredo, J. R., Beckers, J. F., Bevers, M. M., \& Van Den Hurk, R. (1994). Isolation and characterization of preantral follicles from foetal bovine ovaries. The Veterinary Quarterly, 16(2), 7880. doi: 10.1080/01652176.1994.9694423
Lima-Verde, I. B., Matos, M. H. T., Bruno, J. B., Martins, F. S., Santos, R. R., Báo, S. N.,... Lima, P. F. (2009). Effects of $\alpha$-tocopherol and ternatin antioxidants on morphology and activation of goat preantral follicles in vitro cultured. Arquivo Brasileiro de Medicina Veterinária e Zootecnia, 61(1), 57-65. doi: 10.1590/ S0102-09352009000100009

Lucci, C. M., Amorim, C. A., Rodrigues, A. P., Figueiredo, J. R., Báo, S. N., Silva, J. R., \& Gonçalves, P. B. (1999). Study of preantral follicle population in situ and after mechanical isolation from caprine ovaries at different reproductive stages. Animal Reproduction Science, 56(3-4), 223-236. doi: 10.1016/s03784320(99)00045-7

Lucci, C. M., Kacinskis, M. A., Rumpf, R., \& Báo, S. N. (2004). Effects of lowered temperatures and media on short-term preservation of zebu (Bos indicus) preantral ovarian follicles. Theriogenology, 61(2-3), 461-472. doi: 10.1016/s0093-691x(03)00226-7

Matos, M. H. T., Andrade, E. R., Lucci, C. M., Bao, C. N., Silva, J. R. V., Santos, R. R.,... Figueiredo, J. R. (2004). Morphological and ultrastructural analysis of sheep primordial follicles preserved in $0.9 \%$ saline solution and TCM 199. Theriogenology, 62(1-2), 6580. doi: 10.1016/j.theriogenology.2003.07.025

Matzuk, M. M., Dionne, L., Guo, Q., Kumar, T. R., \& Lebovitz, R. M. (1998). Ovarian function in superoxide dismutase 1 and 2 knockout mice. Endocrinology, 139(9), 4008-4011. doi: 10.1210/ endo.139.9.6289

Mclaughlin, M., Bromfield, J. J., Albertini, D. F., \& Telfer, E. E. (2010). Activin promotes follicular integrity and oogenesis in cultured pre-antral bovine follicles. Molecular Human Reproduction, 16(9), 644-653. doi: 10.1093/molehr/gaq021

Migliorisi, G., Folkes, E., Pawlowski, N., \& Cramer, E. B. (1987). In vitro studies of human monocyte migration across endothelium in response to leukotriene B4 and f-Met-Leu-Phe. The American Journal of Pathology, 127(1), 157-167.

Misra, H. P., \& Fridovich, I. (1972). The role of superoxide anion in the autoxidation of epinephrine and a simple assay for superoxide dismutase. The Journal of Biological Chemistry, 47(10), 3170-3175.

Missio, D., Rosa, F. Q., Guimarães, A. C. G., Leivas, F. G., \& Brum, D. S. (2014). Conservação de folículos pré-antrais de felinos domésticos (Felis catus) refrigerados por $24 \mathrm{~h}$ em TCM 199 e PBS. Revista Brasileira de Reprodução Animal, 38(3), 176-181. 
Paynter, S. J. (2000). Current status of the cryopreservation of human unfertilized oocytes. Human Reproducion Update, 6(5), 449-456. doi: 10.1093/humupd/6.5.449

Salehi, P., Spratlin, J., Chong, T. F., \& Churchill, T. A. (2004). Beneficial effects of supplemental buffer and substrate on energy metabolism during small bowel storage. Cryobiology, 48(3), 245-253. doi: 10.1016/j. cryobiol.2004.01.008

Santos, R. R., Silva, J. R. V., Costa, S. H. F., Rodrigues, A. P. R., Lôbo, R. N. B., \& Figueiredo, J. R. (2002). Effect of $0.9 \%$ saline solution and phosphate buffer saline at different temperatures and incubation times on the morphology of goat preantral follicles. Brazilian Journal of Veterinary Research and Animal Science, 39(5), 254-259. doi: 10.1590/S141395962002000500007

Sugino, N. (2007). The role of oxygen radical-mediated signaling pathways in endometrial function. Placenta, 28(Suppl.), 133-136. doi: 10.1016/j. placenta.2006.12.002

Sun, Y., Oberley, L. W., \& Li, Y. (1998). A simple method for clinical assay of superoxide dismutase. Clinical Chemistry, 34(3), 497-500. doi: 10.1093/ clinchem/34.3.497
Suzuki, T., Sugino, N., Fukaya, T., Sugiyama, S., Uda, T., Takaya, R.,... Sasano, H. (1999). Superoxide dismutase in normal cycling human ovaries: immunohistochemical localization and characterization. Fertility and Sterility, 72(4), 720726.doi: 10.1016/s0015-0282(99)00332-5

Valko, M., Leibfritz, D., Moncol, J., Cronin, M. T., Mazur, M., \& Telser, J. (2007). Free radicals and antioxidants in normal physiological functions and human disease. The International Journal of Biochemistry and Cell Biology, 39(1), 44-84. doi: 10.1016/j.biocel.2006.07.001

Wang, S., He, G., Cheng, M., Zuo, T., Xu, W., \& Liu, X. (2017). The role of antioxidant enzymes in the ovaries. Oxidative Medicine and Cellular Longevity, 2017(2017), 1-14. doi: 10.1155/2017/4371714

Zhang, J. M., Wang, H. C., Wang, H. X., Ruan, L. H., Zhang, Y. M., Li, J. T.,... Zhang, Y. C. (2013). Oxidative stress and activities of caspase-8, -9 , and -3 are involved in cryopreservation-induced apoptosis in granulosa cells. European Journal of Obstetrics and Gynecology and Reproductive Biology, 166(1), 52-55. doi: 10.1016/j.ejogrb.2012.09.011 
